\title{
Mentoring Approaches Preferred by Mentors in Their Work With Immigrant Youths
}

\author{
Gila Cohen Zilka \\ Correspondence: Bar-Ilan University; Achva Academic College, Israel \\ Received: October 30, $2021 \quad$ Accepted: December 22, $2021 \quad$ Online Published: January 19, 2022 \\ doi:10.5539/res.v14n1p1 URL: https://doi.org/10.5539/res.v14n1p1
}

\begin{abstract}
The aim of the present study was to examine the preferred approach used by mentors to work with immigrant youths, describe how they carry out their work and why they chose to work that way, and analyze what is their initial assumption in their work with immigrant youths. The approaches are personal growth, mentoring as situational learning, mentoring that focuses on problem-solving problem and mentoring as a research process. One hundred and fifty mentors participated in the study. Each of them worked regularly with five Israeli immigrant youths. The findings show that the mentors adapted the work process to their mentees, but chose an approach that best suited their personality and worldview. A mentor who preferred the "mentoring as personal growth" approach may find it difficult to work in the "mentoring as situational learning" approach. All mentors mentioned a sense of mission they had in working with immigrant youths. The mentors used concepts such as "awareness" and "mindfulness," and spoke about the attention that allows the mentor and mentee a focused view of the present, of what is happening here and now, as a key to a meaningful process in each of the approaches. All the mentors mentioned the principle of communication as a central principle in their work and the importance of having a meaningful dialogue with the mentees. Another principle mentioned by all the mentors was that of building trust between them and their mentees. They developed the mentees' confidence in themselves and their abilities, in the sense that they were capable enough to act, perform, and succeed; and developed trust in the fact that the mentors did want what was best for the mentees, accepting the mentees with their strengths, impulses, and weaknesses.
\end{abstract}

Keywords: immigrant, mentoring, equal opportunity, field experiences

\section{Introduction}

Migration is a process of transition from one culture to another that usually involves numerous changes in many aspects, dealing with physiological, emotional, mental, and social changes, and disconnecting from the process of socialization in the country of origin. The aim of the present study was to examine the preferred approach used by mentors to work with immigrant youths, describe how they carry out their work and why they chose to work that way, and analyze what was their basic assumption in their work with immigrant youths. The mentoring process experienced by immigrant youths is of great importance, and the mentors who work with them were trained before they began their work. In their training process, the mentors were exposed to four mentoring approaches and analyzed events according to each approach. They learned the potential of each approach in simulations of crisis situations, experimenting with designing programs and milestones for handling the crises that arose. Throughout the learning process they faced the question "Who am I as a mentor?" The present article examined the work of mentors of immigrant youths on the theoretical basis of four approaches to mentoring: mentoring as personal growth, mentoring as situational learning, mentoring that focuses on problem solving, and mentoring as a research process. Each mentor worked regularly with five young new immigrant mentees.

\section{Immigrant Youths}

Immigrants often encounter problems related to language, choice of area of residence, housing, economic issues, and difficulties in the process of adapting to the new society and culture. At times, there is a tension between the immigrants' cultural outlook and their daily experiences in the new society, and such tensions aggravate the distress of immigrant children (Choi, 2008; Maldonado-Molina, Reingle, Wesley et al., 2011; Rossiter \& Rossiter, 2009; Spallek et al., 2010; Yearwood et al., 2007; Zilka, 2019, 2020a). The decision to emigrate from one country to another is usually made by parents and not by children. The process of integration in a new country places immigrants in a bilingual and bicultural situation. Lack of command of the language was found to be the most prominent difficulty in the functioning of new immigrants. Another difficulty is the lack of control over pragmatic aspects of the socio-cultural context, such as irony, humor, rhetorical questions, and more; therefore, socio-cultural mediation in oral and written communication is very 
important. As they acquire language skills, immigrants learn the patterns of discourse and internalize the pragmatic-rhetorical aspects of the language

(Budría et al., 2018; McCarty, 2018; Nesterko et al., 2018; Puigdevall et al., 2018; Repke \& Benet-Martínez, 2018; Sevinç \& Dewaele, 2018; Spörlein \& Kristen, 2018; Zilka, 2019; Zorlu \& Hartog, 2018).

Adolescence is a period characterized by a process of identity formation and of coping with changes, including physiological, emotional, mental, and social ones. Studies (Birch \& Ladd, 1997, 1998; Zilka, 2015, 2017, 2020a, 2020b) indicate that in the wake of immigration, the wellbeing, ability to study, sense of self-worth, and social connectedness of young people may be impaired. This may lead to dysfunction in various areas, and even to social deviance. Therefore, the mentors who work with immigrant youths must create for them an environment that fosters feelings of belonging, protection, growth, and ability, and that allows meaningful interactions, positive experiences, and successes, reinforcing their sense of self-worth, of being relevant, and of contribution to the environment (Birch \& Ladd, 1997, 1998; Zilka, 2017, 2018, 2020b).

\section{Mentors for Immigrant Adolescents}

Mentors of immigrant adolescents work in a culturally and linguistically diverse environment. They must know the background of their mentees and the characteristics of various cultures, and avoid, as much as possible, placing their mentees in risk situations (Zilka, 2018, 2020a). Daloz (Daloz 1987) noted that the role of the mentor is a holistic one: the mentor must be attentive and involved in the mentee's life, maintain an ongoing dialogue with the mentees about their problems, help them formulate their wishes, and formulate with them a work plan that suits their needs and areas of interests. Such a work plan should enable mentees to deal with emotional and social difficulties, and should reinforce their strong sides. Its purpose is to help mentees track progress toward achieving their academic, social, and emotional goals. Daluz characterized a successful mentor as somebody who enables mentees to become aware of their situation, motivates them, and helps them overcome their difficulties and fears in a process that leads to the mentees' transformation and affects their identity and personality. The mentors should develop their work methods taking into account several components (Daloz, 1987; Kagan, 1982; Winnicott, 1965; Zilka, 2017, 2020a): trust between the mentor and the mentee, identifying goals, ongoing dialogue, and creating a protected space to give the mentee a sense of security.

\section{Mentoring Approaches}

Four approaches to mentoring, learned in the course of training are (a) personal growth, (b) situational learning, (c) problem-based, and (d) research process (Becher \& Orland-Barak, 2016; Orland-Barak \& Wang, 2020; Zilka, 2015, 2018).

1. Personal growth approach. This approach is based on humanistic psychology, which emphasizes the importance of the mentee's personal growth and wellbeing, and on the self-direction theory, which emphasizes the self as a central agent in human functioning (Ryan et al., 2013; Maslow, 1962; Rogers, 1982). The working principles underlying this approach are psychological and emotional support as a key factor in the growth and development of a positive self-image of the mentee (Gold, 1996; Kelchtermans \& Deketelaere, 2016). Growth is defined as a gradual development process, characterized by provision for the mentee's specific needs, such as motivation and a sense of efficacy (Beijaard et al., 2004; Tschannen-Moran \& Hoy, 2007; Kemmis et al., 2014). In this approach, the role of the mentor is to show empathy to the personal needs of the mentees and assist them in solving personal problems (Israel et al., 2014). Emotional support on the part of the mentor plays an important role in assisting the adolescents in the adjustment process, in reducing pressure, and in coping with personal distress (Hastings, 2008; Shoffner, 2009). According to this approach, the mentor must help mentees identify and solve their personal, academic, and social problems, without coercing them. Mentors must also establish personal relationships with the mentees and care about their personal problems and needs. According to this approach, emotional support is a central principle in the work of the mentor. The mentee's progress is gradual and takes place in stages. Motivation and a sense of personal ability are factors that influence the way immigrant youths will act and cope.

2. Situated learning approach. This approach is based on the social psychology of learning (Brown et al., 1989), which emphasizes the role of context in shaping what and how people learn and how human knowledge becomes meaningful (Resnick, 1991). From this point of view, knowledge develops socially, when individuals take part in their community, and only then is it internalized on the personal level (Edwards \& Protheroe, 2003; Lave \& Wenger, 1991). According to this approach, the mentors guide mentees in adapting to the environment, focusing on the demands that the environment places on them, and seek to help mentees adapt to the requirements.

3. Problem-based approach. This approach is based on behavioral-cognitive psychology, which emphasizes the importance of adapting learning from one context to another, as long as these involve similar conditions (Anderson, 1989; Anderson et al., 1996; Grossman et al., 2009). According to this approach, whenever there is a problem, it is 
treated at different levels. Various solutions of different degrees of depth are suggested, in other words, the mentor responds to what is happening. Usually, work according to this approach begins with understanding the problem, followed by analysis of the context, the need, and the factors; suggesting ways to solve the problem, evaluating the ideas, and critical thinking; planning how to solve the problem, and making and implementing decisions; and finally, reflection on the process.

4. Research approach. This approach is based on critical pedagogy (Freire, 1970; Giroux \& McLaren, 1986; Kincheloe et al., 2000). According to this approach, the mentor's work is based on processes of investigation and ongoing, collaborative, and continuous critique of the work with the mentee. The mentee must develop knowledge from observation and inquiry, and the role of the mentor is to help the mentee examine, observe, understand (Cochran-Smith \& Lytle, 2009). Usually, work according to this approach begins with helping the mentees understand the situation, ask questions, collect information about their habits and behavior patterns, analyze the data collected, present arguments, come up with solutions, and decide on a course of action, followed by learning from the experience (Bruce \& Casey, 2012; Mäeots et al., 2008; Pedaste, et al., 2015; Scanlon et al., 2011). In such situations, the mentor assists the mentees with their requests, analyzing the situation and balancing the mentee's request and need against what is expected of the mentee.

The aim of the present study was to examine the preferred approach used by mentors to work with immigrant youths and analyze the basic assumptions in their work with immigrant youths.

Research questions: What are the approaches that mentors prefer in their work with immigrant youths, how do they choose, and why? What is the mentors' initial assumption in their work with immigrant youths?

\section{Method}

We performed discourse analysis on data obtained from the answers to open-ended questions based on the approaches of Adler and Adler (2008), Atkinson and Delamont (2006), and Hammersley (2008). We identified distinguishing elements and formulated contrasting, complementary, and explanatory themes based on the approaches of Baskarada (Baskarada, 2014), Braun and Clarke (2006), Pope and Mays (2009), Spencer et al. (2003), and Tracy (Tracy, 2019).

Statement analysis was supported by the "topic analysis" approach (Braun et al., 2018; Mihas, 2019), which focuses on the messages extracted from the texts, with emphasis on contextual discourse analysis of the complexity of the education process involving immigrant adolescent mentees. The analysis included the following steps: at the beginning of the process, similar statements were identified to create a division of each of the categories and its components, and a summary table was constructed for each category, presenting the components of that category.

\section{Sample}

One hundred and fifty mentors participated in the study, 122 of them women. Each mentor worked regularly with five young Israeli immigrant mentees. All mentors have completed their professional training and received a certificate. For the mentoring as personal growth approach, 42 mentors were selected (28\%); for the situational learning approach, 54 mentors $(36 \%)$; for the problem-based approach 27 mentors (18\%); and for the research approach, 27 (18\%) of the total number of participants.

\section{Research Tools}

1. Demographic details, such as age, sector, gender, and marital status.

2. Documentation and writing. Mentors were asked to document their meetings with mentees, and then to address in writing the questions: Who am I as a mentor? What is my initial assumption in my work with my mentees?

Mentors could write as they wished, and if necessary, use the following guidelines provided to study participants: Give one or more example from your experience with the mentees, Describe what the problem was, what you did, how you chose to act, whether you achieved the stated goal, what the challenges, successes, and difficulties were?

3. Interviews. After data collection and analysis, we conducted interviews with 28 mentors, seven for each approach. The interviews were semi-structured and addressed the topics that were included in the study variables, but the order of the questions was determined according to the dynamics that developed in the course of the interviews. The interviewees wanted to share the events from their experiences, both positive and negative, and some of them even went into detailed descriptions. The duration of each interview ranged from 15 to 25 minutes.

\section{Research Process}

We sent invitations to participate in the study to mentors working with immigrant youths who have completed their education at a college that trains mentors. Those who agreed completed questionnaires and documentation sheets, and some were interviewed. The mentors worked with five permanent mentees each. The youths were all immigrants, $50 \%$ 
of whom immigrated from Russia, Ukraine, and other countries from the former USSR; 25\% were immigrants from France; $10 \%$ from the US; $5 \%$ from Argentina and Peru, and the rest from other countries. The data were collected in 2019.

\section{Findings}

In this section we present the findings about which approaches the mentors prefer to choose when working with immigrant youths, and why? What is the initial assumption of mentors in their work with immigrant youths?

The data collected were analyzed by approach, according to the emphases given by the mentors. Of 150 mentors who participated, 42 (28\%) chose the personal growth approach, 54 mentors $(36 \%)$ chose the situational learning approach, 27 (18\%) mentors chose the problem-based approach, and 27 (18\%) mentors chose the research approach.

\subsection{Mentor's Initial Assumption}

Table 1. The mentor's initial assumption in working with mentees (the table shows the number of participants who mentioned the principles presented, separated into the different approaches)

\begin{tabular}{|c|c|c|c|}
\hline $\begin{array}{l}\text { Personal growth mentoring } \\
\text { approach } \\
\mathrm{n}=4228 \%\end{array}$ & $\begin{array}{c}\text { Situational learning } \\
\text { mentoring approach } \\
n=5436 \%\end{array}$ & $\begin{array}{c}\text { Problem-based mentoring } \\
\text { approach } \\
\mathrm{n}=2718 \%\end{array}$ & $\begin{array}{c}\text { Research mentoring } \\
\text { approach } \\
\mathrm{n}=2718 \%\end{array}$ \\
\hline $\begin{array}{l}\text { Emphasis on emotional } \\
\text { aspects, communication } \\
\text { with mentees. } \\
\text { The principles noted as } \\
\text { most important by the } \\
\text { mentors were to establish a } \\
\text { personal connection } \\
\text { between the mentor and the } \\
\text { mentee (42); the mentees } \\
\text { should trust the mentors } \\
\text { and understand that the } \\
\text { mentors want the mentees' } \\
\text { good as they are and as } \\
\text { they see their own good } \\
\text { (39), and not as the mentor } \\
\text { sees their good (36). } \\
\text { Assisting mentees to } \\
\text { identify and solve their } \\
\text { personal, academic, and } \\
\text { social problems, without } \\
\text { forcing them (39). } \\
\text { Expressions of concern } \\
\text { regarding the personal } \\
\text { problems and needs of the } \\
\text { mentees (39). }\end{array}$ & $\begin{array}{l}\text { Emphasis on adaptation as } \\
\text { a key to the success of the } \\
\text { immigration process, on } \\
\text { development of social } \\
\text { skills, and on providing } \\
\text { positive feedback to } \\
\text { mentees. } \\
\text { The principles noted as } \\
\text { most important by the } \\
\text { mentors were adaptation to } \\
\text { the new environment (54); } \\
\text { helping mentees in } \\
\text { understanding the } \\
\text { requirements posed by the } \\
\text { environment and the habits } \\
\text { common in the new } \\
\text { environment (54); assisting } \\
\text { mentees to adapt to these } \\
\text { demands, understanding the } \\
\text { requirements and their } \\
\text { significance for the success, } \\
\text { of the mentees' } \\
\text { immigration process (50); } \\
\text { academic assistance, } \\
\text { especially in the acquisition } \\
\text { of the new language (54) } \\
\text { and acquaintance with the } \\
\text { culture in the new country } \\
\text { (50). } \\
\text { Values: belonging, } \\
\text { adaptation a }\end{array}$ & $\begin{array}{l}\text { Emphasis on } \\
\text { problem-solving processes, } \\
\text { development of } \\
\text { cognitive-behavioral } \\
\text { involvement. } \\
\text { The mentor responded to } \\
\text { the problem raised by the } \\
\text { mentee. Whenever there } \\
\text { was a problem, it was } \\
\text { treated at different levels } \\
\text { (27); assisting mentees in } \\
\text { reaching different solutions } \\
\text { at different depths (24); the } \\
\text { mentor as a "big brother" } \\
\text { who helps solve emerging } \\
\text { problems before they } \\
\text { become "large and } \\
\text { complex" (22); solving } \\
\text { problems with the } \\
\text { participation of the } \\
\text { mentees, displaying an } \\
\text { optimistic positive attitude, } \\
\text { with faith in the mentees' } \\
\text { strengths and out of desire } \\
\text { to help (22). }\end{array}$ & $\begin{array}{l}\text { Emphasis on research } \\
\text { processes, observation, } \\
\text { cause-and-effect, process } \\
\text { understanding. Creating an } \\
\text { atmosphere of respect and } \\
\text { support. } \\
\text { Knowledge of the mentees, } \\
\text { understanding how they see } \\
\text { things, what their strengths } \\
\text { and difficulties are, what } \\
\text { requires work (25); tackling } \\
\text { doubts and challenges } \\
\text { along the way (24). } \\
\text { By using this method the } \\
\text { mentors felt that they were } \\
\text { contributing to the mentees } \\
\text { in a way that was tailored } \\
\text { to their needs (22). } \\
\text { Values: observation, } \\
\text { awareness, assessment } \\
\text { ability, attention. and } \\
\text { mindfulness }\end{array}$ \\
\hline
\end{tabular}

Characteristics of the mentees and mentoring centers

Table 2. Creating a mentee profile. Mapping the strengths and weaknesses of the mentee. Identifying the areas that need improvement and focusing the mentoring process on them (the table shows the number of participants who mentioned the principles presented, separated into the different approaches) 


\begin{tabular}{|c|c|c|c|}
\hline $\begin{array}{c}\text { Personal growth mentoring } \\
\text { approach } \\
\mathrm{n}=4228 \%\end{array}$ & $\begin{array}{c}\text { Situational learning } \\
\text { mentoring approach } \\
n=5436 \%\end{array}$ & $\begin{array}{c}\text { Problem-based mentoring } \\
\text { approach } \\
\mathrm{n}=2718 \%\end{array}$ & $\begin{array}{c}\text { Research mentoring } \\
\text { approach } \\
\mathrm{n}=2718 \%\end{array}$ \\
\hline $\begin{array}{l}\text { Focusing action on the } \\
\text { mental wellbeing of the } \\
\text { mentee (42), even at the } \\
\text { expense of other untreated } \\
\text { areas (30). Mentors wrote } \\
\text { that the mentees valued the } \\
\text { respect the mentors showed } \\
\text { toward them and therefore } \\
\text { respected the mentors in } \\
\text { return, cooperated with } \\
\text { them, and agreed to engage } \\
\text { in a work process (28). In } \\
\text { this approach, the work } \\
\text { process was gradual, } \\
\text { guided by the specific } \\
\text { needs expressed by the } \\
\text { mentees, bringing the } \\
\text { mentees to the } \\
\text { understanding } \\
\text { awareness of other areas, } \\
\text { stimulating motivation and } \\
\text { a sense of ability to deal } \\
\text { with other aspects, such as } \\
\text { language acquisition, and } \\
\text { continuing studies in } \\
\text { various fields (38). } \\
\text { First, it is important for } \\
\text { mentees to feel that they } \\
\text { are in a protected place and } \\
\text { that their emotional and } \\
\text { social needs are addressed } \\
\text { before the academic issues } \\
\text { (26). }\end{array}$ & $\begin{array}{l}\text { Emphasis on social aspects, } \\
\text { on conversations aimed at } \\
\text { understanding the context } \\
\text { of every issue that comes } \\
\text { up, in an attempt to clarify } \\
\text { the meaning of the issue } \\
\text { both in its specific and } \\
\text { broad context (54);to give } \\
\text { the mentees the sense of } \\
\text { belonging, of a protected } \\
\text { place, of someone to turn to } \\
\text { when there is a problem } \\
\text { (52). } \\
\text { When mentees understand } \\
\text { what is happening around } \\
\text { them, their acclimatization } \\
\text { is likely to happen faster. } \\
\text { When they understand what } \\
\text { others are doing and what } \\
\text { the requirements are, it cuts } \\
\text { the time of adapting to the } \\
\text { requirements, and when } \\
\text { they experience successes } \\
\text { in many areas, their } \\
\text { situation improves and } \\
\text { provides additional } \\
\text { motivation to deal with the } \\
\text { difficulties of integration } \\
\text { (52). } \\
\text { The mentors who used this } \\
\text { approach wrote that the } \\
\text { approach did not focus on } \\
\text { difficulties but rather on } \\
\text { paving the way to success } \\
\text { (51). When the mentees } \\
\text { experienced a difficulty, the } \\
\text { mentor listened, allowed } \\
\text { space for the difficulty, } \\
\text { contained, and helped, but } \\
\text { the emotional aspect was } \\
\text { not the central one (50). }\end{array}$ & $\begin{array}{l}\text { Assisting mentees to } \\
\text { identify and solve their } \\
\text { personal, academic, and } \\
\text { social problems (27) } \\
\text { without being judgmental, } \\
\text { without criticism or } \\
\text { admonition (27); forging } \\
\text { personal and deep } \\
\text { relationships based on } \\
\text { listening, cooperation, } \\
\text { reflection, and affection, } \\
\text { with the main goal of } \\
\text { helping mentees cope with } \\
\text { the challenges they face } \\
\text { (25). } \\
\text { The mentees turned to } \\
\text { mentors when they had a } \\
\text { problem in a particular } \\
\text { area, or with a particular } \\
\text { teacher, social problems in } \\
\text { the classroom or during } \\
\text { breaks, with the knowledge } \\
\text { that the mentors would help } \\
\text { them bridge the gap created } \\
\text { by the problem before the } \\
\text { difficulty became complex } \\
\text { and serious. } \\
\text { The mentees knew that the } \\
\text { mentors were there for } \\
\text { them in any crisis that may } \\
\text { emerge, to help them } \\
\text { overcome any obstacle } \\
\text { (23); the mentees were } \\
\text { encouraged to trust in their } \\
\text { ability to deal with crises; } \\
\text { they had a support circle to } \\
\text { turn to when they felt } \\
\text { distressed ( } 24) \text {. }\end{array}$ & $\begin{array}{l}\text { Creating an opening for a } \\
\text { process of exploration, } \\
\text { cooperation, expression of } \\
\text { opinion, and doubting so } \\
\text { that the mentees understood } \\
\text { that the process was theirs, } \\
\text { with the assistance of the } \\
\text { mentors (24). } \\
\text { Most of the time, } \\
\text { adolescents wanted help } \\
\text { with social issues. Some } \\
\text { felt disconnected or had a } \\
\text { sense of not belonging; } \\
\text { therefore it was important } \\
\text { to help them socially. } \\
\text { Mentors wrote that when } \\
\text { the mentees felt that they } \\
\text { belonged, other aspects } \\
\text { would also be resolved, } \\
\text { including educational and } \\
\text { emotional. At this age, } \\
\text { social affiliation is very } \\
\text { important (23). } \\
\text { The principle noted by the } \\
\text { mentors was to achieve the } \\
\text { realization of the mentee's } \\
\text { strengths for } \\
\text { self-fulfillment and for } \\
\text { optimal communication } \\
\text { with the mentee (21). }\end{array}$ \\
\hline
\end{tabular}

Guiding principles in mentoring practices

Table 3. The work process according to guiding principles in mentoring practices

\begin{tabular}{|c|c|c|c|}
\hline $\begin{array}{l}\text { Personal growth mentoring } \\
\text { approach } \\
n=4228 \%\end{array}$ & $\begin{array}{c}\text { Situational learning } \\
\text { mentoring approach } \\
\mathrm{n}=5436 \%\end{array}$ & $\begin{array}{c}\text { Problem-based mentoring } \\
\text { approach } \\
\mathrm{n}=2718 \%\end{array}$ & $\begin{array}{c}\text { Research mentoring } \\
\text { approach } \\
\mathrm{n}=2718 \%\end{array}$ \\
\hline $\begin{array}{l}\text { The most important guiding } \\
\text { principle mentioned by the } \\
\text { mentors was interpersonal } \\
\text { communication between } \\
\text { the mentee and the mentor, } \\
\text { characterized by }\end{array}$ & $\begin{array}{l}\text { The guiding principle } \\
\text { mentioned by the mentors } \\
\text { was to create in the } \\
\text { mentees a sense of } \\
\text { belonging, while they } \\
\text { adapted to the new }\end{array}$ & $\begin{array}{l}\text { The guiding principle } \\
\text { mentioned by the mentors } \\
\text { was building a bond of trust } \\
\text { and care, } \\
\text { to enable crisis } \\
\text { management and problem }\end{array}$ & $\begin{array}{l}\text { The mentees must produce } \\
\text { knowledge by means of } \\
\text { observation and inquiry, } \\
\text { and the role of the mentors } \\
\text { was to help them examine, } \\
\text { observe, and understand }\end{array}$ \\
\hline
\end{tabular}




\begin{tabular}{|c|c|c|c|}
\hline $\begin{array}{c}\text { Personal growth mentoring } \\
\text { approach } \\
\mathrm{n}=4228 \%\end{array}$ & $\begin{array}{c}\text { Situational learning } \\
\text { mentoring approach } \\
n=5436 \%\end{array}$ & $\begin{array}{c}\text { Problem-based mentoring } \\
\text { approach } \\
\mathrm{n}=2718 \%\end{array}$ & $\begin{array}{c}\text { Research mentoring } \\
\text { approach } \\
\mathrm{n}=2718 \%\end{array}$ \\
\hline $\begin{array}{l}\text { cooperation, understanding, } \\
\text { caring, sensitivity, and } \\
\text { openness, so that the } \\
\text { mentee would feel } \\
\text { comfortable with the } \\
\text { mentor. To be a figure that } \\
\text { the mentees can open up to } \\
\text { without being ashamed or } \\
\text { afraid, mentors should be } \\
\text { able to identify whether } \\
\text { there are personal issues in } \\
\text { the family, at school, with } \\
\text { friends or teachers. }\end{array}$ & $\begin{array}{l}\text { environment, to the group, } \\
\text { and to the class. The } \\
\text { mentors helped their } \\
\text { mentees identify and solve } \\
\text { their personal, academic, } \\
\text { and social problems by } \\
\text { means of group, and if } \\
\text { necessary personal } \\
\text { conversations; mentors } \\
\text { helped mentees understand } \\
\text { the new environment and } \\
\text { its characteristics, the } \\
\text { challenges they } \\
\text { encountered, all along } \\
\text { paying attention to the } \\
\text { mentees' social difficulties. }\end{array}$ & $\begin{array}{l}\text { solving. Conducting a } \\
\text { dialogue with the mentees } \\
\text { about their difficulties, their } \\
\text { demands and the demands } \\
\text { from them, the pressures } \\
\text { experienced by them, their } \\
\text { desires, goals, and dreams. } \\
\text { Finding solutions to } \\
\text { problems together with the } \\
\text { mentees, with a positive } \\
\text { and optimistic attitude, with } \\
\text { trust in the mentees' } \\
\text { strengths, and out of a } \\
\text { desire to help them undergo } \\
\text { a process of transformation. } \\
\text { To induce the mentees to } \\
\text { come up with various } \\
\text { solutions with the } \\
\text { understanding that a real } \\
\text { solution was one that suited } \\
\text { the mentees and provided a } \\
\text { solid foundation for them to } \\
\text { continue on their way . } \\
\text { The mentees should feel } \\
\text { that the solution was right } \\
\text { for them and that they were } \\
\text { able to meet demands, } \\
\text { conditions, and schedules. }\end{array}$ & $\begin{array}{l}\text { causes and effects, } \\
\text { understand the situations } \\
\text { and sequence of events; } \\
\text { help the mentees ask } \\
\text { questions, suggest } \\
\text { solutions, analyze and } \\
\text { address situations, and } \\
\text { learn from experience. In } \\
\text { such situations, the mentor } \\
\text { helped mentees examine } \\
\text { whatever it was that the } \\
\text { mentees wanted to find out } \\
\text { or check. }\end{array}$ \\
\hline
\end{tabular}

Table 4. Characteristics of reflection

\begin{tabular}{|c|c|c|c|}
\hline $\begin{array}{c}\text { Personal growth mentoring } \\
\text { approach } \\
n=4228 \%\end{array}$ & $\begin{array}{c}\text { Situational learning } \\
\text { mentoring approach } \\
\mathrm{n}=5436 \%\end{array}$ & $\begin{array}{c}\text { Problem-based mentoring } \\
\text { approach } \\
\mathrm{n}=2718 \%\end{array}$ & $\begin{array}{c}\text { Research mentoring } \\
\text { approach } \\
\mathrm{n}=2718 \%\end{array}$ \\
\hline $\begin{array}{l}\text { Emotional discourse. } \\
\text { Expression of emotions and } \\
\text { feelings. An open and free } \\
\text { discourse on any topic } \\
\text { brought up by the mentees, } \\
\text { assisting them in coming up } \\
\text { with ways to handle the } \\
\text { difficulties, break through } \\
\text { the barriers, and advance } \\
\text { along a new path. }\end{array}$ & $\begin{array}{l}\text { The mentors listened to the } \\
\text { mentees in a mirroring } \\
\text { process and acknowledged } \\
\text { the importance of the } \\
\text { mentees' angle of viewing } \\
\text { things, of the expressed } \\
\text { feelings and difficulties as } \\
\text { existential and real, with } \\
\text { emphasis on the fact that } \\
\text { the mentors did not } \\
\text { underestimate the difficulty } \\
\text { raised by the mentees. }\end{array}$ & $\begin{array}{l}\text { From the mentees' point of } \\
\text { view, their problems were } \\
\text { existential, preventing them } \\
\text { from opening up and } \\
\text { developing, from realizing } \\
\text { their potential, and } \\
\text { integrating into the social } \\
\text { fabric. Therefore, the } \\
\text { mentors also perceived the } \\
\text { mentees, problems as } \\
\text { substantial existential } \\
\text { problems. }\end{array}$ & $\begin{array}{l}\text { The key to the success of } \\
\text { the research process was } \\
\text { observed. Observing the } \\
\text { sequence of events, } \\
\text { gathering information, } \\
\text { distinguishing between } \\
\text { facts, feelings, and } \\
\text { emotions, understanding } \\
\text { cause-and-effect relations, } \\
\text { and defining milestones for } \\
\text { future action. }\end{array}$ \\
\hline
\end{tabular}

\section{Excerpts From the Mentors' Responses for Each Approach}

\subsection{Personal Growth Mentoring Approach}

"All along, the most important thing for me is the personal connection between me and my mentees. It's important to me that they trust me, that they believe I want what's best for them, that they feel comfortable talking to me openly, that they can always come to me and tell me about their experiences and problems, anything they wish. They are not afraid of me and are not afraid to disappoint me, they know I'm on their side. "Accepting America as new Home

"My mentees have a difficult life, with many challenging experiences, and once they know they have a mentor who believes in them, they cooperate and engage in a growth process. It's very important to me that they know I care about 
them, that I'm here for them."

"The basis for my identity as a mentor is caring. I'll never be indifferent or uncaring toward my mentees. Naturally, every mentee of mine is deep in my heart, and I always find a bright spot in every one of them."

"In my job as a mentor, I first of all believe in mutual trust between me and the mentee. I think the best way to educate is to form deep bonds with the mentee. When a mentee trusts the mentor and when there is mutual trust between them, anything can be done. I have a place for my mentees, he knows that he can be himself, no judgment, with empathy."

"I succeed in forging personal and deep connections that are based on listening, sharing, reflection, and great affection. I believe I manage to give them a sense that someone is listening to them and seeing them, and always wants only what's best for them, thus improving their experience of integration in the new country."

\subsection{Situational Learning Mentoring Approach}

"Right from the start of our relationship, it was important for me to make it clear to them that I care about their opinions and feedback, so that the classes would be interesting and help them advance, and that they can tell me everything and it will be fine. I didn't want any censorship of what they supposedly were not allowed to tell me by virtue of my being their mentor."

"I'm a kind of 'big sister,' a listening ear, a confidante for the mentees to talk to. Approval, listening, and acceptance. I was exposed to complex cases, the experiences and realities of life of my mentees are not simple. I presented learning as a way to accumulate successes and face challenges. I raised the requirements for my mentees and learned that one should not be afraid to raise the bar, even if at first it's not always welcome. My mentoring style created a somewhat distant mentoring at first glance, but in practice, it was intimate and meaningful. I learned the importance of professional mentoring, and how it allows me to make happen the personal development of each of my mentees."

"The first two-three months of work with new mentees are very complex and unclear. I rely on intensive communication with my mentees, which is not easy because of the language gap, and I try to pay attention, as much as possible, to their feelings and emotions. I find games and activities to bridge the language gap between us. I emphasize personal attitude, social integration, and meeting the needs of the mentees. "

"Mentoring in my opinion means being a significant figure for my mentees. With each of my mentees, I face the challenge of teaching a language that is my mother tongue, but not theirs."

\subsection{Problem-Based Mentoring Approach}

"It's important to me that they adapt to the new society. My mentees experience crises, and that's exactly where I am to help them overcome any obstacles along the way, encourage them not to give up easily, to always believe in themselves."

"There are a lot of difficulties, gaps in language and understanding (some of them are really new immigrants who have just arrived in the country), but despite the many difficulties, I believe that the problem-solving approach is best for me in my work with immigrant youths."

"Every meeting with my mentees starts with my asking how they feel, whether there is anything they want to talk about, whether they need help. They share with me their problems and difficulties, thoughts and concerns, and I help them throughout the process of defining the difficulty, clarifying, understanding the problem, analyzing the context and the need, suggesting possible creative ideas about how to solve the problem, defining milestones, making decisions, and implementing the chosen solution."

"Each time I teach them new ways of dealing with problems, difficulties, and challenges. And every time I see how each of my mentees manages to deal with problems."

"I really feel that I'm going through an amazing process with my mentees, and even though sometimes it's hard, painful, and complex, I feel satisfied and happy to see them cope and succeed. I'm happy to have been given the privilege to help. It's unparalleled satisfaction, and when I see their progress, I go to bed at night with a smile, and realize I'm doing something good."

"I get to know each and every one of my mentees deeply, they're my rays of light. This is how together we managed to achieve impressive success academically, socially, and emotionally, and to overcome all the obstacles, difficulties, and problems along the way."

\subsection{Research Mentoring Approach}

"I came across mentees who initially scorned the process, didn't arrive on time, didn't do what was required of them, disrupted the normal course of the lesson. I initiated with them a process of exploration and sharing, of voicing opinions, doubts, and observation. Once they understand that this is an opportunity, a process of building trust begins, a process of observation that leads to openness and development." 
"Every mentee has his own path to success. What guides me as a mentor is my mentee's own way, point of view. What guides me as a mentor is my mentee's path, his point of view, and I adapt myself to the place he's in. That's why I work with them using the research approach."

"In my opinion, the most important thing is to help them go through a process that meets their needs, and therefore mentoring based on the research method is the most appropriate for me. Because the mentee is the one who determines the perspectives and the important points."

"One of my mentees is in 10th grade, a fresh new immigrant from Russia (less than a year in the country), and she's experiencing academic and social difficulties. From the beginning, things just clicked between us (I spoke a few words of Russian with her so I believe it gave her a little support), and I realized that what I want to do is to help her deal with basic things that she's not been able to deal with. We worked using the research method, and in the process so many things became clearer; a thick fog enveloping her just dissipated."

\section{Discussion}

The aim of the present study was to examine the preferred approach used by mentors to work with immigrant youths, describe how they carry out their work and why they chose to work that way, and analyze what the initial assumption in their work with immigrant youths is. The approaches were mentoring as personal growth, mentoring as situational learning, mentoring that focuses on problem solving, and mentoring as a research process.

All mentors cited communication as a central principle in their work with mentees, and the importance of having a meaningful dialogue with them. It was important for the mentors that mentees felt that the mentors were with them and for them. Dialogue with mentees (Zilka, 2014, 2017) should be existential, making it clear to mentees that the mentors take their problems seriously, see these problems as existential, and want to help them open up and develop, without arguing or attempting to persuade. In a dialogue, the mentees reveal their thoughts, attitudes, and beliefs at their own pace and in their own time, after which the fog dissipates, allowing them to see with greater clarity what the mentees' wishes are, and help them achieve their goals. The mentors must listen attentively and respond to the mentees with understanding and empathy, without passing judgment, imparting on the mentees a sense that the mentor understands and empathizes with their difficulties. When the mentees feel that the mentors understand their difficulties and accept their feelings, they are likely to develop a sense of trust and closeness, of friendly communication, and express a willingness to cooperate.

The findings show that the mentors distinguished between "routine" and "putting out fires," even if according to them, the latter was a permanent component of their routine. For example, one of the mentees had social problems, there was an incident of a verbal clash, and the mentor dealt with the issue at the level of "putting out fires," but then the mentor helped the mentee address the issue in depth. The findings show that "firefighting" is more commonly used by mentors working according to the situational approach. This can be explained by the fact that in practice, with the situational approach, the mentors place emphasis in their work on the mentees' belonging and adaptation to the new society. The mentee is in the process of adjusting to society, requirements, customs, and rules, so there are more crises in their work than in that of mentors who work using other approaches. At the same time, in some of the other approaches, the process of adapting to society is not a priority for mentors in their work.

Another important principle mentioned by all the mentors working with immigrant youths was building trust between them and their mentees; building the mentees' confidence in themselves and in their abilities; developing their sense that they are able to act, perform, and succeed; belief that the mentors want what is best for the mentees, and that they accept the mentees with their strengths, impulses, and weaknesses. Many mentors mentioned that some of their mentees felt distrust toward the most significant adults in their lives. Children and adolescents need to feel and know with certainty that if a problem arises they can always count on having someone to help them find ways to deal with the difficulties, without criticism and judgment, but with empathy and willingness (Daloz, 1987; Zilka, 2014, 2015, 2017).

The mentors indicated, each in a different context, that they adapted the work process to their mentees, yet chose to work in an approach that better suited their own personality. A mentor who chose the "mentoring as personal growth" approach found it difficult to work with the "mentoring as situational learning" approach. All mentors spoke of the sense of mission they felt when working with immigrant youths. In each of the approaches, the mentors used concepts such as "awareness" and "mindfulness," referring to attention that allows the mentor and mentee to observe intentionally, in the present, what is happening here and now, as a key to a meaningful process.

\section{Mentoring With a Personal Growth Approach}

The mentors who chose this approach (28\%) responded that this was the approach that suited them, their personality, and their work with immigrant youths. Some claimed that they chose this approach because they found that without addressing emotional aspects, there was no chance of making progress, achieving a breakthrough in working with their mentees. This approach is based on humanistic psychology and the theory of self-direction, which emphasizes the self as 
a central agent in human functioning, and psychological and emotional support as key factors in the growth and development of the mentee's positive self-image (Gold, 1996; Kelchtermans \& Deketelaere, 2016). A key component is affectivity — respect for the other's choice, furnishing a protected and shared space, making room for the other, showing concern and tolerance of the differences that exist between human beings, allowing one to make personal choices without harming others. It is important to avoid embarrassing the other, as most people, and especially children and adolescents, are afraid of rejection, of a situation that might humiliate or embarrass them, of being reprimanded in public. These fears may cause them to refrain from acting, from experiencing, and from expressing themselves. Therefore, affectivity allows mentees to express themselves freely and spontaneously, and to feel that they are in a protected space. It is important not to force them to do things that would cause them to "bottle up" their sensibilities, to give a place for their feelings and their desire for closeness or distancing (Zilka, 2018). The mentors emphasized that the mentees' mental wellbeing was the focus of all action, even at the expense of other aspects that remain untreated. They noted that the work in this approach was a gradual process, guided by the specific needs expressed by the mentee during the process. These findings are consistent with those of previous studies (Beijaard et al., 2004; Tschannen-Moran \& Hoy, 2007; Zilka, 2017). The mentors stated that, in their opinion, the role of the mentor was to empathize with the needs of the mentees, help them solve personal problems, and help them in the process of adjustment by relieving feelings of stress, without forcing anything on them. Mentors must conduct an open and free emotional dialogue with the mentees on any subject raised by the latter, to help them cope with difficulties, overcome obstacles, and move on to a new path.

\section{Mentoring as Situational Learning}

The mentors who chose this approach (36\%) stated that the guiding principle was to produce a sense of belonging when adapting to the new environment, of belonging to the group and to the class. The mentors affirmed that they worked hard to help mentees adjust so that they would develop a sense of belonging, and help mentees identify and solve their personal, academic, and social problems, in group conversations, and if necessary individually. The objective was for mentees to understand the new environment and its characteristics, and the challenges they faced, with emphasis on paying attention to the social difficulties of the mentees. According to mentors, when the mentees understand what is happening around them, their adaptation may happen faster. When they understand what others do and what the requirements are, it saves them time and they comply with the requirements sooner, experiencing successes in many areas, improving their situation, and motivating them to deal with the difficulties of integration. This approach is based on social psychology, according to which knowledge develops socially when individuals participate in the community, and only then is knowledge internalized on the personal level (Edwards \& Protheroe, 2003; Lave \& Wenger, 1991). The mentors who participated in this study indicated that they assisted their mentees by paying attention to academic success, acquisition of the new language, and acquaintance with the culture and customs of the new country. The mentors emphasized adaptation as a key to the success of the immigration process, and noted that this approach did not focus as much on difficulties but more on paving the way for success.

\section{Mentoring With a Problem-Solving Approach}

The mentors who chose this approach $(18 \%)$ stated that the guiding principle was to develop a problem-solving process together with the mentee, with an optimistic, positive attitude, belief in the mentee's strengths, and out of a desire to help the mentee experience transformation. They stated that they did not limit themselves to discussions about problems and to providing emotional support to the mentee, but rather treated the mentees and their difficulties as substantial problems that require assistance to solve in practice. They were not in a hurry to provide answers and solutions but preferred to discuss the problem with the mentees and raise options, provide tools for coping, thus turning the exchange into an existential dialogue. There should be understanding that the mentees' problems are existential ones that prevent them from opening up and developing, realizing themselves and integrating into the social fabric, which therefore should be perceived by themselves as well as by the mentors as serious existential problems. The problems presented by the mentees should not be underestimated. The work process mentioned by the mentors focused on identifying and solving problems together with the mentees, creatively, by proposing ideas and through innovation. This approach is based on the behavioral-cognitive psychology of learning (Anderson 1989; Anderson et al., 1996; Grossman et al., 2009). The mentors explained that first the solutions suggested by the mentees should be listed, without passing judgment. A judgmental view of the solutions suggested by the mentees was liable to give them a sense of being relieved of their responsibility and commitment to the process. Next, the positive and negative aspects of the suggested solutions, the constraints, and the chances of success must be elucidated and organized in a logical and easy-to-understand form, to enable choosing the best solution for the mentee. A good solution is the one that suits the mentee, allowing to build a solid foundation for further experiences. The mentees should feel confident that the solution is right for them, and that they can meet requirements, conditions, and schedules. The mentors indicated that the mentees turned to them when they had a problem in a particular area, or with a particular teacher, a social difficulty in class or during breaks, and that they knew that the mentors would help them bridge the gap created by the problem before the difficulty became complex and serious. 


\section{Mentoring With the Research-Based Approach}

The mentors who chose this approach (18\%) reported that they focused on inquiry processes and active, collaborative, and continuous review of the research process with the mentee. The mentor helped the mentee come to an understanding through observation and inquiry, by examining the circumstances, asking questions, suggesting solutions, and drawing conclusions. The mentors assisted the mentees in satisfying their requests, after having examined the situation and balanced what the mentee wanted and needed with the requirements from the mentee. Participating mentors who chose other approaches spoke a similar language, but only in the research approach did participants use various characteristics and descriptions of the research process, as experienced with their mentees. Some of the mentors described the processes of exploring possible courses of action, others indicated processes of exploration that would help mentees develop awareness and grow. There was a common desire among mentors to embark together with their mentees on an exploratory journey to dissipate the fog and help mentees define their difficulties; then, out of the identified difficulty, formulate a positive goal that could help the mentees mobilize forces for experience and change. The mentors stated that they were involved throughout the research stages, helping their mentees overcome obstacles and face challenges. They noted that in their role as mentors they needed to be in a state of awareness and intentionality, to absorb information that would help them assist their mentee. They must pay attention, be mindful of things that happen, engage in contemplation, be tolerant, empathic, and accepting of whatever may come up in the research process. The key to the success of the research process was observation, absorption of information (overt and covert), and transformation of information into practical, existential knowledge that can assist mentees in their developmental process (Zilka, 2017, 2018).

In conclusion, mentors work in a culturally and linguistically diverse environment and must develop the ability to operate in a multicultural climate, and recognize the different backgrounds of their mentees. They must have conceptual knowledge of the characteristics of different cultures, and avoid as much as possible risk situations that their mentees may find themselves in. Mentors need to be on the lookout to identify the strengths of their mentees in various areas, and once they have found such strengths, create opportunities to cultivate and promote them. Each mentor chose an approach that was likely to advance the mentees and give them a sense of resilience. Mentors strove for the mentoring approach to advance their mentees toward openness and development, help them establish meaningful interactions with those around them, adapt to their environment, develop appropriate skills, and build social connections. Mentors attached great importance to the interaction between them and their mentee, to helping mentees deal with their difficulties, to providing positive feedback to mentees, and to creating an atmosphere of respect and support.

\section{Future Research}

In this study, we examined the approaches mentors chose for working with immigrant adolescents, from their own perspective. A follow-up study should examine the issue from the perspective of the mentees, immigrant youths: how they see their mentors' work, what the mentors focus on, and what their own needs and the needs of their mentors are.

\section{References}

Adler, P. A., \& Adler, P. (2008). Of Rhetoric and Representation: The Four Faces of Ethnography. The Quarterly Sociological, 49(1), 1-30. https://doi.org/10.1111/j.1533-8525.2007.00104.x

Anderson, G. L. (1989). Critical ethnography in education: Origins, current status, and new directions. Review of Educational Research, 59(3), 249-270.

Anderson, J. R., Reder, L. M., Simon, H. A. (1996). Situated learning and education. Educational Researcher, 25(4), 5-11. https://doi.org/10.3102/0013189X025004005

Atkinson, E., \& Delamont, S. (2006). In the roiling smoke: qualitative inquiry and contested fields. International Journal of Qualitative Studies in Education, 19(6), 747-755. https://doi.org/10.1080/09518390600975974

Baskarada, S. (2014). Qualitative case study guidelines. The Qualitative Report, 19(40), 1-25.

Becher, A., \& Orland-Barak, L. (2016). Integrating social activity theory and critical discourse analysis: A multilayered methodological model for examining knowledge mediation in mentoring. International Journal of Qualitative Studies in Education, 29(4), 498-519.

Beijaard, D., Meijer, P. C., \& Verloop, N. (2004). Reconsidering research on teachers' professional identity. Teaching and Teacher Education, 20(2), 107-128. https://doi.org/10.1016/j.tate.2003.07.001

Birch, S. H., \& Ladd, G. W. (1997). The teacher-child relationship and children's early school adjustment. Journal of School Psychology, 35, 61-79. https://doi.org/10.1016/S0022-4405(96)00029-5

Birch, S. H., \& Ladd, G. W. (1998). Children's interpersonal behaviors and teacher-child relationships. Developmental Psychology, 34, 934-946. 
Braun, V., \& Clarke, V. (2006). Using thematic analysis in psychology. Qualitative Research in Psychology, 3(2), 77e101. https://doi.org/10.1191/ 1478088706qp063oa

Braun, V., Clarke, V., Hayfield, N., \& Terry, G. (2018). Thematic analysis. Handbook of research methods in health social sciences, 1-18.

Brown, J. S., Collins, A., Duguid, P. (1989). Situated cognition and the culture of learning. Education Researcher, 18(1), 32-34. https://doi.org/10.3102/0013189X018001032

Bruce B. C., \& Casey, L. (2012). The practice of inquiry: A pedagogical 'sweet spot' for digital literacy? Computers in the Schools, 29 (1-2), 191-206. https://doi.org/10.1080/07380569.2012.657994

Budría, S., Colino, A., \& Martínez de Ibarreta, C. (2018). The impact of host language proficiency on employment outcomes among immigrants in Spain. Empirica, Journal of European Economics, 1-28. https://doi.org/10.1007/s10663-018-9414-x

Choi, Y. (2008). Diversity within: Subgroup differences of youth problem behaviors among Asian Pacific Islander American adolescents. Journal of Community Psychology, 36(3), 352-370. https://doi.org/10.1002/jcop.20196

Cochran-Smith, M., \& Lytle, S. L. (2009). Inquiry as stance: Practitioner research for the next generation. Teachers College Press.

Daloz, A. L. (1987). Effective Teaching and Mentoring. Jossey Bass Publishers.

Edwards, A., Protheroe, L. (2003). Learning to see in classrooms: What are student teachers learning about teaching and learning while learning to teach in schools? British Educational Research Journal, 29(2), 227-242. https://doi.org/10.1080/0141192032000060957

Freire, P. (1970). Pedagogy of the oppressed. Herder and Herder.

Giroux, H.A., McLaren, P. (1986). Teacher education and the politics of engagement: The case for democratic schooling. Harvard Educational Review, 53(3), 213-238. https://doi.org/10.17763/haer.56.3.trr1473235232320

Gold, Y. (1996). Beginning teacher support: Attrition, mentoring, and Induction. In J. Sikula, T. J. Buttery, \& E. Guyton (Eds.), Handbook of research on teacher education, 2, 548-616.

Grossman, P., Hammerness, K., McDonald, M. (2009). Redefining teaching, re-imagining teacher education. Teachers and Teaching: theory and practice, 15(2), 273-289.

Hammersley, M. (2008). Questioning Qualitative Research: Critical Essays. Sage.

Hastings, W. (2008). I felt so guilty: Emotions and subjectivity in school-based teacher education. Teachers and Teaching, 14(5-6), 497-513. https://doi.org/10.1080/13540600802583655

Israel, M., Kamman, M. L., McCray, E. D., \& Sindelar, P. T. (2014). Mentoring in action: The interplay among professional assistance, emotional support, and evaluation. Exceptional Children, 81(1), 45-63. https://doi.org/10.1177/0014402914532231

Kagan, R. (1982). The Evolving Self: Problems and Process in Human Development. Cambridge, Mass. Harvard University Press.

Kelchtermans, G., \& Deketelaere, A. (2016). The emotional dimension in becoming a teacher. In J. Loughran \& M.L. Hamilton (Eds.), International handbook of teacher education (pp. 429-461). Springer.

Kemmis, S., Heikkinen, H. L. T., Fransson, G., Aspfors, J., \& Edwards-Groves, C. (2014). Mentoring of new teachers as a contested practice: Supervision, support and collaborative self-development. Teaching and Teacher Education, 43, 154-164. https://doi.org/10.1016/j.tate.2014.07.001

Kincheloe, J., Slattery, P., \& Steinberg, S. (2000). Contextualizing teaching. Longman.

Lave, J., \& Wenger, E. (1991). Situated learning: Legitimate peripheral participation. Cambridge University Press.

Mäeots, M., Pedaste, M., \& Sarapuu T. (2008). Transforming students' inquiry skills with computer-based simulations. 8th IEEE International Conference on Advanced Learning Technologies, 1-5 July.

Maldonado-Molina, M., Reingle, J. M., Wesley, G., Jennings, W.G., \& Prado, G. (2011). Drinking and driving among immigrant and US-born Hispanic young adults: Results from a longitudinal and nationally representative study. Addictive Behaviors, 36(4), 381-388. https://doi.org/10.1016/j.addbeh.2010.12.017

Maslow, A.H. (1962). Toward a psychology of being. Van Nostrand \& Insight Books.

McCarty, T.L. (2018). Comparing 'new speakerhood': context, positionality, and power in the new sociolinguistic order. 
Journal of Multilingual and Multicultural Development, 39(5), 470-474 https://doi.org/10.1080/01434632.2018.1429457

Mihas, P. (2019). Qualitative data analysis. In Oxford Research Encyclopedia of Education.

Nesterko, N., Ulitsa, N., \& Friedrich, M. (2018). Do They Feel the Same Way? Health-Related Quality of Life and Satisfaction with Life in Jewish Immigrants from the Former Soviet Union in Germany and Israel. Journal of Cross-Cultural Psychology, 49(4), 618-634. https://doi.org/10.1177/0022022118759223

Orland-Barak, L., \& Wang, J. (2020). Teacher mentoring in service of preservice teachers' learning to teach: Conceptual bases, characteristics, and challenges for teacher education reform. Journal of Teacher Education, 0022487119894230 https://doi.org/10.1177/0022487119894230

Pedaste, M., Mäeots, M., Siiman, L. A., de Jong, T., van Riesen, S. A., Kamp, E. T., Manoli, C. C., Zacharia, Z., \& Tsourlidaki, E. (2015). Phases of inquiry-based learning: Definitions and the inquiry cycle. Educational research review, 14, 47-61. https://doi.org/10.1016/j.edurev.2015.02.003

Pope, C., \& Mays, N. (2009). Critical reflections on the rise of qualitative research. BMJ, 339, b3425. https://doi.org/10.1136/bmj.b3425

Puigdevall, M., Walsh, J., Amorrortu, E., \& Ortega, A. (2018). 'I'll be one of them': linguistic modes and new speakers in three minority language contexts. Journal of Multilingual and Multicultural Development, 39(5), 445-457. https://doi.org/10.1080/01434632.2018.1429453

Repke, L., \& Benet-Martínez, V. (2018). The (Diverse) Company You Keep: Content and Structure of Immigrants' Social Networks as a Window Into Intercultural Relations in Catalonia. Journal of Cross-Cultural Psychology, 49(6), 924-944. https://doi.org/10.1177/0022022117733475

Resnick, L.B. (1991). Shared cognition: Thinking as social practice. In Resnick, L. B., Levine, J. M., Teasley, S. D. (Eds.), Perspectives on socially shared cognition (pp. 1-20). American Psychological Association. https://doi.org/10.1037/10096-018

Rogers, C. (1982). Freedom to learn in the eighties. Merrill.

Rossiter, M.J., \& Rossiter, K. R. (2009). Immigrant youth and crime: Stakeholder perspectives on risk and protective factors. Working Paper No. WP02-09.

Ryan, R. M., Curren, R. R., \& Deci, E. L. (2013). What humans need: Flourishing in Aristotelian philosophy and self-determination theory. In A. S. Waterman \& A. S. Waterman (Eds.), The best within us: Positive psychology perspectives on eudaimonia (pp. 57-75). American Psychological Association.

Scanlon, E., Anastopoulou, S., Kerawalla, L., \& Mulholland, P. (2011). How technology resources can be used to represent personal inquiry and support students' understanding of it across contexts. Journal of Computer Assisted Learning, 27(6), 516-529. https://doi.org/10.1037/14092-004

Sevinç, Y., \& Dewaele, J. M. (2018). Heritage language anxiety and majority language anxiety among Turkish immigrants in the Netherlands. International Journal of Bilingualism, August 05, 2016. https://doi.org/0123456789123456

Shoffner, M. (2009). The place of the personal: Exploring the affective domain through reflection in teacher preparation. Teaching and Teacher Education, 25(6), 783-789. https://doi.org/10.1016/j.tate.2008.11.012

Spallek, J., Zeeb, H., \& Razum, O. (2010). Prevention among immigrants: the example of Germany. BMC Public Health, 10(1), 1-6.

Spencer, L., Ritchie, J., Lewis, J., \& Dillon, L. (2003). Quality in qualitative evaluation: A framework for assessing research evidence. The Cabinet Office.

Spörlein, C., \& Kristen, C. (2018). Educational Selectivity and Language Acquisition among Recently Arrived Immigrants. International Migration Review. https://doi.org/10.1177/0197918318798343

Tracy, S. J. (2019). Qualitative research methods: Collecting evidence, crafting analysis, communicating impact. John Wiley \& Sons.

Tschannen-Moran, M., \& Hoy, A. W. (2007). The differential antecedents of self-efficacy beliefs of novice and experienced teachers. Teaching and Teacher Education, 23(6), 944-956. https://doi.org/10.1016/j.tate.2006.05.003

Winnicott, D.W. (1965). The Maturational Process and the Facilitating Environment. International University Press.

Yearwood, E. L., Crawford, S., Kelly, M., \& Moreno, N. (2007). Immigrant youth at-risk for disorders of mood: 
Recognizing complex dynamics. Archives of Psychiatric Nursing, 21(3), 62-171. https://doi.org/10.1016/j.apnu.2007.02.006

Zilka, C. G. (2014). Empowering Educators \& Mentors in the Social Media Age - The Three Element Way. Butan-Galim (240 p.). (Hebrew).

Zilka, C. G. (2015). Social competence of children at risk: Similarities and differences among the various assessors. In E. Grupper \& S. Romi (Eds.), Children and adolescents at risk in Israel: The voice of young people and issues faced by child and youth care workers, (2), 113-185. Tel Aviv, Israel: MOFET Institute (Hebrew).

Zilka, C. G. (2017). The Elements Way: Empowering parents, educators, and mentors in the age of new media. Issues in Informing Science and Information Technology, 14, 101-119.

Zilka, C. G. (2018). Working with immigrant children and adolescents at risk: Mentors' use of The Elements Way. Psychology Research, 8(7), 308-321.

Zilka, C. G. (2019). Teenagers connected to digital environments - what happens when they get to school? Commonalities, similarities , and differences from their perspective. Education and Information Technologies, 25, $1743-1758$.

Zilka, C. G. (2019). The use of mobile technologies by immigrant adolescents in coping with the new language and with their formal studies. In A. Forkosh-Baruch, \& H. Meishar-Tal. (Eds.). Mobile technologies in educational organizations, (pp. 192-210). IGI Global, USA.

Zilka, C. G. (2020a). Feelings of belonging or alienation and social emotional perceptions of immigrant youths in the digital age, in comparison with native-born youths. Education and Information Technologies.

Zilka, C. G. (2020b). Use of social networking applications (SNAs) by immigrant children, adolescents, and young adults. International Journal of Mobile Communication, 18(3), 257-272. https://doi.org/10.1504/IJMC.2020.107099

Zorlu, A., \& Hartog, J. (2018). The Impact of Language on Socioeconomic Integration of Immigrants. IZA Discussion Paper No. 11485. Available at SSRN: https://ssrn.com/abstract=3170274

\section{Copyrights}

Copyright for this article is retained by the author(s), with first publication rights granted to the journal.

This is an open-access article distributed under the terms and conditions of the Creative Commons Attribution license (http://creativecommons.org/licenses/by/4.0/). 